\title{
Effects of Naproanilide on Tuberization and RNA Synthesis of Cyperus serotinus Rottb.*
}

\author{
Katsuichiro Kobayashi**, Katsunori Ichinose**, Hiroshi Hyakutake** and \\ Kozo IsHizUKA*** \\ **Laboratory of Herbicides \& Plant Growth Regulators, The Institute of \\ Physical and Chemical Research, Wako, Saitama 351, Japan. \\ ***Institute of Applied Biochemistry, The University of Tsukuba, Ibaraki \\ 305, Japan.
}

In recent years, control of perennial weeds such as $C$. serotinus has beeen a serious problem in paddy fields in Japan, while most of the annual paddy weeds have been relatively easily controlled by herbicides. Since perennial weeds regenerate or propagate through their vegetative parts such as rhizome, tuber or bulb, they are seldom eliminated by herbicides even if their aerial parts are killed. Therefore, inhibition of tuberization by herbicides is an important step in the control of most perennial weeds.

Some herbicides were found to have an inhibitory effect on the tuber formation of C. $\operatorname{serotinus}^{5,7)}$, but it was not clear whether the inhibition occurred directly through their action on tuberization. HARADA et $a l^{11}$. reported that some plant growth regulators inhibited the tuberization of Eleocharis kuroguwai Ohwi, and suggested that the inhibition occurred through the disturbance of the quantitative balance of endogenous growth hormones. KUSANAGI $^{4)}$ pointed that the hormone-type herbicides such as 2,4-D (2,4-dichlorophenoxyacetic acid) inclined to be relatively more effective on tuberization inhibition than other types of herbicides.

Naproanilide[1-(2-naphthoxy)propionailide] is considered to be one of the hormone-type herbicides and has a selective herbicidal activity on cyperaceous and broad-leaved weeds in rice fields ${ }^{10}$. In our previous report ${ }^{2)}$, it was found that naproanilide remarkably stimulated RNA synthesis in susceptible smallflower umbrellaplant ( $C$. diffomis L.) and we suggested that the resulting disturbance of RNA metabolism might induce the observed abnormal growth and subsequent resulting suppression of plant growth. KozAYAsHi et $a l^{32}$. found that naproanilide inhibited the tuberization of $C$. serotinus under a long-day condition, while it had little inhibitory effect on the dry matter growth of the plant. However, the relationship between the inhibitory effects on its tuberization and on the growth of other organs, as well as the biochemical aspects of naproanilide action have not yet been fully studied.

The present study was undertaken to investigate the effect of naproanilide treatment on tuberization at different growth stages in relation to its effects on growth and on RNA synthesis of an individual organ of $C$. serotinus under a short-day condition. Under this condition, tuberization is known to occur earier than under a long-day condition ${ }^{9)}$.

\section{Materials and Methods}

\section{Plant materials and Naproanilide Treat-} ment.

Tubers of C. serotinus were kindly provided by Agricultural Research Center, Ministry of

* A part of this work was reported at the 21 st Annual Meeting of the Weed Science Society of Japan, Konosu, April, 1982. 
Agriculture, Forestry and Fisheries, Konosu, Saitama. The tubers were cut into small sections, each with a bud, and were sprouted in an incubator at $30^{\circ} \mathrm{C}$ for 3 days. Three sprouted tubers were transplanted respectively to a round pot $(113 \mathrm{~mm}$ in diameter, $146 \mathrm{~mm}$ in height) filled with sand and were given $1 \mathrm{~g}$ of compound fertilizer $(8-8-6)$ in a controlled environmental room. The room was maintained at $28^{\circ} \mathrm{C}$ under illumination provided by metal halide lamps (Toshiba DR $400 / \mathrm{TL}$ ) for $8 \mathrm{hr}$ and $23^{\circ} \mathrm{C}$ in the dark for 16 $\mathrm{hr}$; relative humidities were $55 \%$ and $75 \%$, respectively. Light intensity was about 30 klux at the surface of the pot. Seven days after transplanting, the plants were thinned to one per pot. Naproanilide was applied to the plant at the five different growth stages shown in Table 1. A one hundred $\mathrm{ml}$ aqueous solution of naproanilide of various concentrations, containing $1 \%$ acetone and $0.1 \%$ Tween $20^{\circledR}$, was poured into the water in the pot.

The beginning of tuber formation was observed at the 5-leaf stage which was about 40 days after the sprout of the mother tuber. Harvests were made 3 weeks after the beginning of tuber formation when treated with naproanilide at the 2- to the 5-leaf stages.

At the 6-leaf stage treatment, harvesting was done 3 weeks after the treatment. At harvest, the daughter hills were first separated from the mother plant, and then the numbers of hills, rhizomes and tubers were counted. Dry weights were determined after separation of the plant into parts. Treatment was replicated three times.

In order to distinguish between the effects on tuber inition and on tuber enlargement, another experiment was conducted as follows: at the 6-leaf stage, tubers already formed were marked with paint prior to the naproanilide treament to distinguish them from those formed after the treatment. Three weeks after treatment, the marked and the newly formed tubers vere respectively separated from the rhizomes. Half of each group was individually sprouted in an incubator at $30^{\circ} \mathrm{C}$ for 10 days, while the other half was weighed to determine the dry weight.

\section{Incorporation Study of Radioactive Uracil into RNA.}

Naproanilide was applied at the dosage of $3 \mathrm{~kg} /$ ha at the four different growth stages (Table 3) corresponding to the experiment on growth effect just described. The plants were harvested 1,3 and 7 days after treatment and washed with water. Mother plants were used as the materials for the incorporation study. The basal parts of shoots (about $3 \mathrm{~cm}$ ), the rhizomes except for those which had already developed into shoots or tubers, the roots and the tubers were used for the incorporation of ${ }^{14} \mathrm{C}$-uracil (specific activity: 58 $\mathrm{mCi} / \mathrm{mM}$ ) into RNA.

Each organ was cut into small sections, and the sections were incubated in $10 \mathrm{ml}$ of incubation medium $[0.01 \mathrm{M}$ phosphate buffer $(\mathrm{pH}$ 6. 0 ), $1 \%$ sucrose, $1 \mu \mathrm{Ci}$ uracil- $2-{ }^{14} \mathrm{C}$, and 8 ppm chloramphenicol]. After incubation for $6 \mathrm{hr}$ at $30^{\circ} \mathrm{C}$, fractionation and RNA estimation were done according to the method of Ogur and Rosen as modified by Mrzuno ${ }^{6)}$; the radioactivity of ${ }^{14} \mathrm{C}$ incorporated into $\mathrm{RNA}$ was determined, details of which were previously reported $^{2)}$. The rate of RNA synthesis was expressed by the amount of incorporated ${ }^{14} \mathrm{C}$ per dry weight $(\mathrm{dpm} / \mathrm{mg})$ and per RNA content $\left(\mathrm{dpm} / \mathrm{OD}_{260}\right)$. Treatment was replicated three times.

\section{Results and Discussion}

\section{Effects of Naproanilide on Growth and Tuberization.}

Our previous study ${ }^{3)}$ indicated that the tuberization of $C$. serotinus was remarkably suppressed by naproanilide regardless of growth stage under a long-day condition. But the relationship between the suppression of tuberization and the effect on growth of other organs was not clear, since a large quantity 
Table 1. Effects of naproanilide treated at the five different growth stages on the growth and tuberization of C. serotinus ${ }^{1)}$.

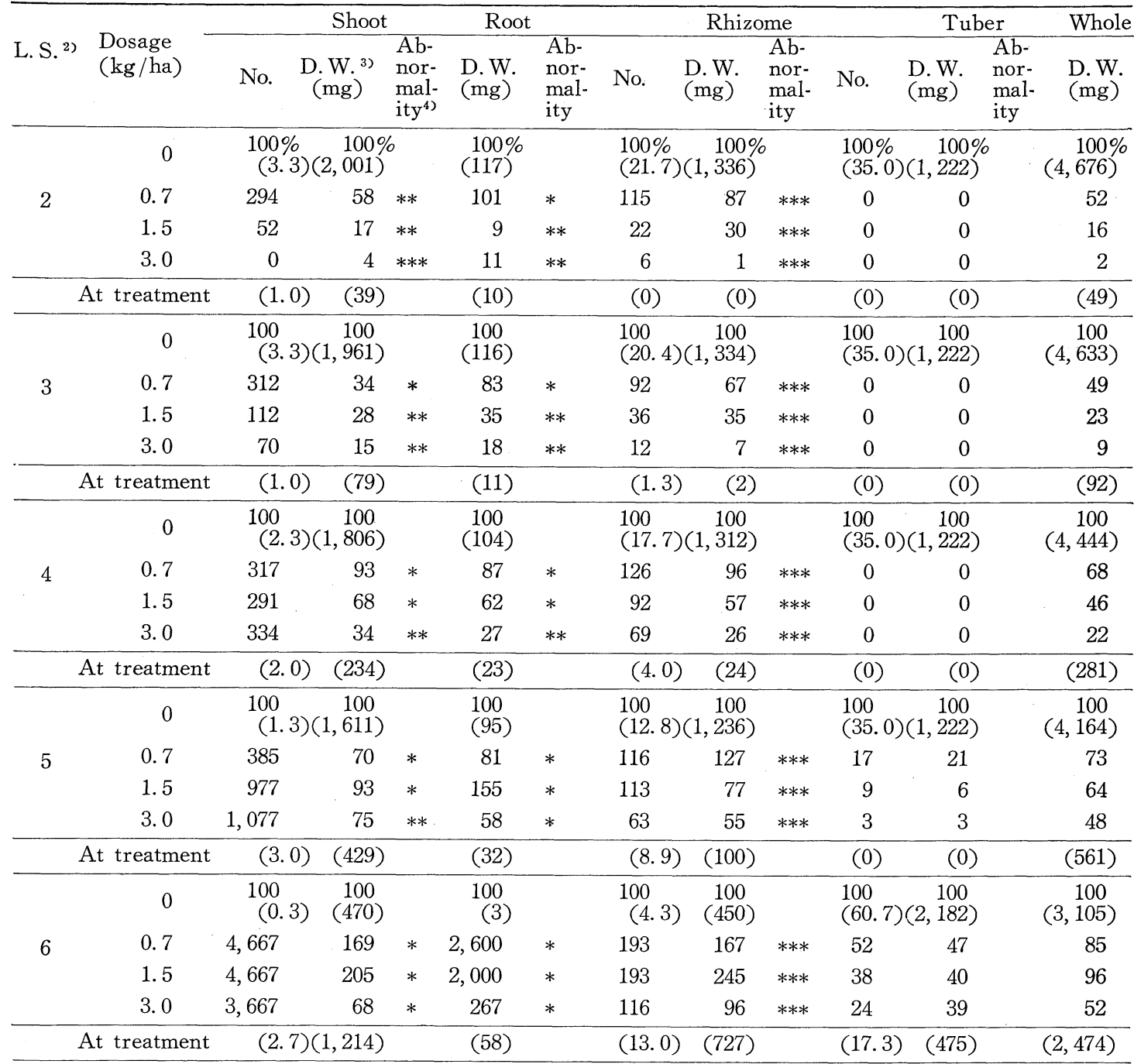

1) Data are presented as a percent of the control except for values in parentheses indicating one per pot. Each value at harvest indicates the net growth after treatment.

2) L.S.: leaf stage at naproanilide-treated time.

3) D. W.: dry weight.

4) The number of asteriskes $(*)$ indicates the degree of abnormality observed at harvest, and none indicates no abnormality.

of dry matter was produced concomitant with more hills and the beginning of tuberization took longer under the long-day condition. Suge and Kusanagi ${ }^{9)}$ reported that the tuberization of C. serotinus was greatly enhanced, the dry matter suppressed, and fewer hills present under a short-day condition in comparison with a long-day condition. The prelim- inary study indicated that the tuber formation of this plant grown under the short-day condition described in Materials and Methods was observed about 40 days after sprouting of the mother tuber, whereas tuber formation under a long-day condition (16 hr illumination) was observed only after about 70 days.

Under the short-day condition, the effects 
of naproanilide on the growth of the individual organs and on the tuberization of C. serotinus were studied. Results are shown in Table 1 (data per individual hill are not shown).

i) Effect of Naproanilide on Growth.

The dry matter growth of shoots per pot or per individual hill was remarkably suppressed, and necrosis in the top of young leaves of the mother plant was induced by any dosage of naproanilide when treated at the 2- and the 3-leaf stage. The inhibitory effect on dry matter growth of the mother shoot was diminished if treatment was delayed after the sprouting of the mother tuber; this was especially remarkable in the 4 - or the 5-leaf stage treatment. With naproanilide treatment during tuberization(the 6-leaf stage), the dry matter growth of the mother shoot was scarcely inhibited at any dosage. However, the herbicide did suppress dry matter shoot growth in the daughter hills, the degree of suppression being similar to that of the corresponding stages of the mother shoot (the 2or 3-leaf stage). At the 4- or 5- leaf stage treatment, such suppression was similarly observed.

Abnormal swelling caused by naproanilide in the basal parts of young shoots was observed in both mother and daughter plants treated at the younger stages, but such abnormality diminished as the growth stage of shoots of treated plants advanced. On the contrary, the number of daughter hills of a treated plant increased compared with control, no matter how severely the dry matter growth was suppressed, such as in the case of the 2- or the 3-leaf stage treatment at a dosage of $0.7 \mathrm{~kg} / \mathrm{ha}$. The increasing effect on hill production was enhanced even more remarkably when the treatment was delayed.

Dry matter growth of roots per pot or per hill was noticeably decreased, and abnormal stumping in the top of newly developed roots was observed to some degree in both mother and daughter plants by naproanilide treated at the 2- or the 3-leaf stage. The inhibitory and formative effects on root growth were diminished with the delay of treatment. The relationship between the effect on root growth and time of treatment was similar to that seen in the shoots.

The inhibitory effects of the herbicide on dry matter growth and on the production of rhizome from the shots were found to be very large when treated at the 2- or 3-leaf stage, but were less with delayed treatment. On the other hand, abnormal swelling and twisting in both the top and the internode of rhizomes were strongly induced by naproanilide regardless of age when treated; this was observed not only in new rhizomes but also in older ones which had developed into shoots or tubers.

ii) Effect of Naproanilide on Tuberization.

Tuber formation of C. serotinus was completely inhibited by naproanilide treatment at the 2 - to the 4-leaf stage (Table 1.). However, the inhibitory effect was diminshed slightly when treated at the 5-leaf stage, which was the beginning of tuber formation, and was noticeably diminished when treated during tuberization (the 6-leaf stage). At the 5- and 6 -leaf stages, it was considered that some, but not all, of the rhizomes had already developed into tubers even tuber formation was not observed. Therefore, the effects on the development of rhizomes into tuber and on the enlargement of the already formed tuber when naproanilide was applied during tuberization were separately measured (Table 2). The number of tubers of the treated plant formed after treatment was much less than that of control. But, the individual dry weight of the pre-formed and newly formed tuber was almost the same as control. On the other hand, the sprouting rate of both new tubers and these already formed were scarcely inhibited by naproanilide, and they grew up normally. The results demonstrated that naproanilide inhibited rhizome development into tuber without suppression of the enlargement 
Table 2. Effects of naproanilide treated during tuberization (the 6-leaf stage) on the formation, enlargement and sprouting activity of $C$. serotinus tubers.

\begin{tabular}{|c|c|c|c|c|c|c|c|}
\hline \multicolumn{3}{|c|}{ At treatment } & \multicolumn{2}{|c|}{ At harvest } & & & \\
\hline \multicolumn{2}{|l|}{ Dosage } & \multicolumn{3}{|c|}{ Tubers existing before treatment } & \multicolumn{3}{|c|}{ Tubers formed after treament } \\
\hline$(\mathrm{kg} / \mathrm{ha})$ & $\begin{array}{l}\text { Number } \\
\text { (per pot) }\end{array}$ & $\begin{array}{l}\text { Number } \\
\text { (per pot) }\end{array}$ & $\begin{array}{l}\text { Dry weight } \\
\text { (mg/tuber) }\end{array}$ & $\begin{array}{l}\text { Rate of } \\
\text { sprouting } \\
(\%)\end{array}$ & $\begin{array}{l}\text { Number } \\
\text { (per pot) }\end{array}$ & $\begin{array}{l}\text { Dry weight } \\
\text { (mg/tuber) }\end{array}$ & $\begin{array}{l}\text { Rate of } \\
\text { sprouting } \\
(\%)\end{array}$ \\
\hline 0 & 31 & 31 & 43 & 97 & 41 & 25 & 90 \\
\hline 0.7 & 28 & 28 & 38 & 86 & 18 & 16 & 100 \\
\hline 1.5 & 32 & 32 & 38 & 88 & 5 & 30 & 100 \\
\hline 3.0 & 20 & 20 & 54 & 90 & 7 & 23 & 86 \\
\hline
\end{tabular}

or the sprouting of daughter tubers. It was suggested that the inhibitation of tuberization was induced at the point of tuber initiation.

These results indicated that the inhibitory and formative effects of naproanilide on shoot and root growth of C. serotinus were diminished as growth stages advanced after treatment; this was similar to the effects shown on the growth of smallflower umbrellaplant ${ }^{2}$. Rhizome abnormality was induced by the herbicide regardless of age when treated, while the inhibitory effect on dry matter growth was diminished with delay in treatment. Tuber initiation was inhibited by naproanilide treated in any growth stage, and it was noted there was a good correlation between the formative effect on rhizome and the inhibitory effect on tuber initiation. It thus appears that naproanilide directly inhibits tuber initiation through action on the developmental function of rhizome which has an ability to differentiate into tuber; this is quite separate from the effect on the growth of shoot or root. The inhibition of shoot or root growth indirectly induces the inhibition of tuberization as a results of the growth suppression of the whole plant.

Effect of Naproanilide on RNA Synthesis.

Effect of naproanilide on RNA synthesis in the shoots, roots, rhizomes and tubers was studied at certain intervals following treatment at different growth stages of $C$. serotinus. Results are shown in Table 3.
In shoots, no significant stimulation in RNA synthesis was found 1 day after treatment at any given growth stage. Three days after treatment, RNA synthesis of the treated plants was apparently stimulated in comparison with that of the control independent of age. Seven days after treatment, the stimulation of synthesis was further enhanced when it had been treated at the $2-$ and the 4-leaf stage, while this effect was diminished in 5- and 6-leaf stage treatment. The stimulation of RNA synthesis in shoots was thus enhanced much more in the early than in the mature stage, and good correlation was found to exist between the stimulative effect on this synthesis and the inhibitory effect on shoot growth.

The stimulative effect of naproanilide on RNA synthesis in rhizomes concomitant with increase in RNA content was notable after 3 days, and these effects were further enhanced 7 days after treatment regardless of age at treatment; no effect had been observed after 1 day. Such stimulative effect on RNA synthesis was much clearer in the expression of uracil incorpopation into RNA per dry weight than per RNA content, which indicated that naproanilide induced not only the stimulation of rate of synthesis but also the increase of RNA content. The results demonstrated that the stimulative effect on RNA synthesis was not diminished in spite of the delay in naproanilide treatment, which effect was quite different from the case in shoot. It was noted that the stimulative effect on RNA synthesis in rhizomes 
Table 3. Effect of naproanilide ( $3 \mathrm{~kg} / \mathrm{ha})$ applied at the four different growth stages on RNA synthesis in shoot, rhizome and tuber of C. serotinus at various intervals after treatment ${ }^{11}$.

\begin{tabular}{|c|c|c|c|c|c|c|c|c|c|}
\hline \multirow[t]{2}{*}{ L.S. ${ }^{2)}$} & \multirow{2}{*}{$\begin{array}{l}\text { Days } \\
\text { after } \\
\text { treatment }\end{array}$} & \multicolumn{2}{|c|}{ Shoot } & \multicolumn{2}{|c|}{ Root } & \multicolumn{2}{|c|}{ Rhizome } & \multicolumn{2}{|c|}{ Tuber } \\
\hline & & \multicolumn{2}{|c|}{$\mathrm{dpm} / \mathrm{mg} \mathrm{dpm} / \mathrm{OD}^{3)}$} & \multicolumn{2}{|c|}{$\mathrm{dpm} / \mathrm{mg} \mathrm{dpm} / \mathrm{OD}$} & \multicolumn{2}{|c|}{$\mathrm{dpm} / \mathrm{mg} \mathrm{dpm} / \mathrm{OD}$} & \multicolumn{2}{|c|}{$\mathrm{dpm} / \mathrm{mg} \mathrm{dpm} / \mathrm{OD}$} \\
\hline \multirow{3}{*}{2} & 1 & $\begin{array}{r}\% \\
103\end{array}$ & $\begin{array}{l}\% \\
98\end{array}$ & $\begin{array}{r}\% \\
123\end{array}$ & $\begin{array}{r}\% \\
103\end{array}$ & $\begin{array}{r}\% \\
-4)\end{array}$ & $\%$ & $\%$ & $\%$ \\
\hline & 3 & 128 & 138 & 98 & 88 & - & - & - & - \\
\hline & 7 & 320 & 404 & 115 & 85 & - & - & - & - \\
\hline \multirow{3}{*}{4} & 1 & 111 & 116 & 110 & 96 & 100 & 105 & - & - \\
\hline & 3 & 151 & 148 & 82 & 84 & 133 & 105 & - & - \\
\hline & 7 & 280 & 185 & 122 & 121 & 258 & 122 & - & - \\
\hline \multirow{3}{*}{5} & 1 & 92 & 94 & 128 & 122 & 130 & 118 & - & - \\
\hline & 3 & 132 & 101 & 96 & 93 & 178 & 112 & - & - \\
\hline & 7 & 116 & 85 & 99 & 125 & 345 & 128 & - & 一 \\
\hline \multirow{3}{*}{6} & 1 & 96 & 79 & 119 & 129 & 112 & 97 & 73 & 91 \\
\hline & 3 & 142 & 120 & 90 & 84 & 149 & 80 & 100 & 88 \\
\hline & 7 & 112 & 111 & 105 & 90 & 211 & 169 & 196 & 164 \\
\hline
\end{tabular}

1) Data are presented as percent of the control.

2) L.S. indicates leaf stage at time of treatment.

3) Absorbance at $260 \mathrm{~nm}$.

4) Bar $(-)$ indicates that the organ did not exist at time of treatment.

was correlated with the formative effect, rather than with the inhibitory effect on rhizome growth.

On the other hand, RNA synthesis in roots tended to be scarcely stimulated not only 1 day but also 3 or 7 days after treatment at any given growth stage. In tuber, RNA synthesis was remarkably stimulated 7 days after treatment at the 6-leaf stage.

These results demonstrated that RNA synthesis in rhizome was more remarkably stimulated than in other organs regardless of the age at treatment, although the relationship between the effects on growth and on RNA synthesis in roots or tubers was not made clear in this study. It is generally accepted that rhizome develops into a tuber or shoot, and the process is closely related to the endogenous plant hormones which are known to act on RNA metabolism ${ }^{8}$. HARADA et al. ${ }^{12}$ reported that some plant growth regulators inhibited the tuber formation of E. Kuroguwai. It thus can be postulated that naproanilide stimulates RNA synthesis in rhizome, and that the resulting disturbance of RNA metabolism might induce the inhibition of tuber initiation concomitant with the stimulation of hill production through action on rhizome developmental function. Whether other hormone-type herbicides inhibit tuberization of C. serotinus in the same manner should be investigated to clarify the relationship between their stimulative effect on RNA synthesis in the rhizome and the inhibitory effect on tuberization.

It is important to emphasize that, among the organs of $C$. serotinus, rhizome was the most sensitive to naproanilide in RNA synthesis. The reason for this different sensitivity requires study in connection with the behavior of the herbicide in the plant and the mechanism of its action on tuberization.

\section{Summary}

Effects of naproanilide [1- (2-naphthoxy) propionanilide] treatment at different growth stages on tuberization and RNA synthesis of C. serotinus Rottb. was studied in relation to its effect on growth. 
The inhibition of tuberization concomitant with the stimulation of hill production and rhizome abnormality were induced regardless of age when treated. The inhibitory and formative effects on the growth of shoot or root were observed in the early stage, but these effects diminished as the growth stage of the treated plant advanced. With treatment during tuberization, tuber initiation was inhibited while neither the enlargement nor the tuber sprouting activity were affected.

RNA synthesis in rhizome, expressed by uracil incorporation into RNA, was stimulated more remarkably than in the other organs by treatmrnt at any given growth stage.

The results suggested that naproanilide inhibited tuber initiation through its action on the RNA synthetic process related to the development of rhizome into tuber.

Acknowledgements : We wish to thank Dr. H. NAKAYAMa, The Institute of Physical and Chemical Research, for his kind advice. We are grateful to Dr. T. KusANAGI, and Dr. Y. Watanabe, Agriculture Research Center, Ministry of Agriculture, Forestry and Fisheries, for their kind advice on $C$. serotinus and for supplying the tubers.

\section{References}

1) Harada, J., K. Shimotsubo and T. Tanaka: Japan Jour. Crop Sci. 47, 395 399 (1978).

2) Kobayashi, K., H. Hyakutage and K. Ishizuka: Weed Res. (Japan) 26, 30 36 (1981).

3) Kobayashi, K., K. Ichinose, H. Hyakutake and K. Ishizuka: Weed Res. (Japan) 25 (Suppl.), 127 128 (1980). (in Japanese).

4) Kusanagi, T.: J. Pesticide Sci. 3, 485 497 (1978). (in Japanese with English summary).

5) Mirahara, M. and K. Nakagawa: Abstr. Ann. Meeting of the Weed Sci. Soc. Japan, 110 112 (1970). (in Japanese).

6) Mrzuno, S.: Methods in quantitative determination and separation of nucleic acid. Tokyo Univ. Press, Tokyo, 56 60 (1969). (in Japanese).

7) Nakagawa, K. and M. Miyahara: Weed Res. (Japan) 6, 107 111 (1967). (in Japanese with English summary).

8) Orazawa, Y.: Chemical Regulation of Plants 14, 67 75 (1979). (in Japanese).

9) Suge, H. and T. Kusanagi: Weed Res. (Japan) 20, 8 11 (1975). (in Japanese with English Summary).

10) TakasaWa, Y., K. Igarashi and T. Takematsu: Rroc. 5 th Asian-Pacific Weed Sci. Soc. Cong., 96 98 (1975).

(Received November 26, 1982).

\title{
ミズガヤツリの塊茎形成およびR N A 生合成に対するNaproanilideの作用
}

\author{
理化学研究所 小林勝一郎・一瀬勝紀・百武 博 \\ 筑波大学 石塚 皓造
}

摘

要

ミズガヤツリ (Cyperus serotinus Rоттв.) の塊茎形成に対する naproanilide [1-(2-naphthoxy) propionanilide】の作用を各器官の生育およびR N A生合成に対する作用との関連で処理時期ごとに調查, 検討した。

1）茎葉および根においては，生育初期の処理で乾物生長の阻害とともに茎葉基部や根端に奇形の発現が認められ た。しかし，これらの作用は，いずれも，処理時期が遅くなるに従って低下した（Table 1)。

2）根茎では，処理時期にかかわりなく，奇形の発現が著しく，この奇形は，先端だけでなくすでに茎葉あるいは 塊茎を形成した節間にも認められた。しかし, 乾物生長の阻害は, 生育初期の処理にのみ認められた (Table 1)。 
3）塊茎の形成は，処理時期にかかわりなく常に強く阻害された（Table 1)。しかし，処理前に形成していた塊茎 の肥大生長は阻害されなかった (Table 2)。また，塊茎の萠芽能も阻害されなかった (Table 2 )。

4）処理時期にかかわりなく, 処理区では, 対照区に比べて, 根茎から発生した茎葉数が増加する傾向が認められ た (Table 1)。

5）上記のように，塊茎形成の阻害と根茎における奇形の発現との間に最も密接な関連性が認められた。

6）各器官の RNA生合成は，処理後 1 日目では，ほとんど影響を受けなかった。根茎のRNA生合成は，処理時 期にかかわりなく, 処理後 3 日目で促進が認められ, 7 日目には, さらに顕著な促進が認められた。茎葉のR RA生 合成は，生育初期の処理で根茎の場合と同様な促進作用が認められたが，処理時期が遅くなると，3 日目に認められ た促進作用は，7 日目にはほとんど認められなかった。根のRNA生合成は，いずれの処理時期においてもほとんど 影響を受けなかった。また，塊茎では，7日目のみに促進作用が認められた（Table 3)。

7）上記のように, 各器官の中で, 根茎の R NA生合成が naproanilide に対して最も高い感受性を示す傾向が認 められた。

8）以上の結果から， naproanilide は，塊茎形成に関連した根茎の R NA生合成系の攂乱を通して根茎の塊茎へ の分化を阻害しているものと推定された。 